\title{
TINJAUAN YURIDIS PERLINDUNGAN KONSUMEN MUSLIM DALAM MENDAPATKAN JAMINAN PRODUK HALAL TERHADAP PEMBELIAN SECARA ONLINE
}

\author{
Oleh : \\ Fadzlurrahman* dan Susilowati Suparto** \\ Email: fadzlurrahman@mail.unpad.ac.id dan susilowati.suparto@unpad.ac.id
}

Abstrak

In 2019, the Indonesian government will target all products circulating in halal-certified Indonesia. While the readiness of the Halal Product Guarantee Agency (BPJPH) is still constrained by a Government Regulation that has not been approved by the President. The development of technology and information makes buying and selling transactions can be done online, there are many products sold online, some of which do not include halal labels in their products. Seeing the inequality between das sollen and das sein, this article formulates the problem of how to guarantee legal protection for the sale of non-halal labeled products sold online as well as any obstacles that must be anticipated by the JPH Law to protect Muslim consumers from obtaining halal products in electronic transactions using normative research method.

Key Word : Consumer Protection, Halal Product Guarantee, E-Commerce

\section{A. PENDAHULUAN}

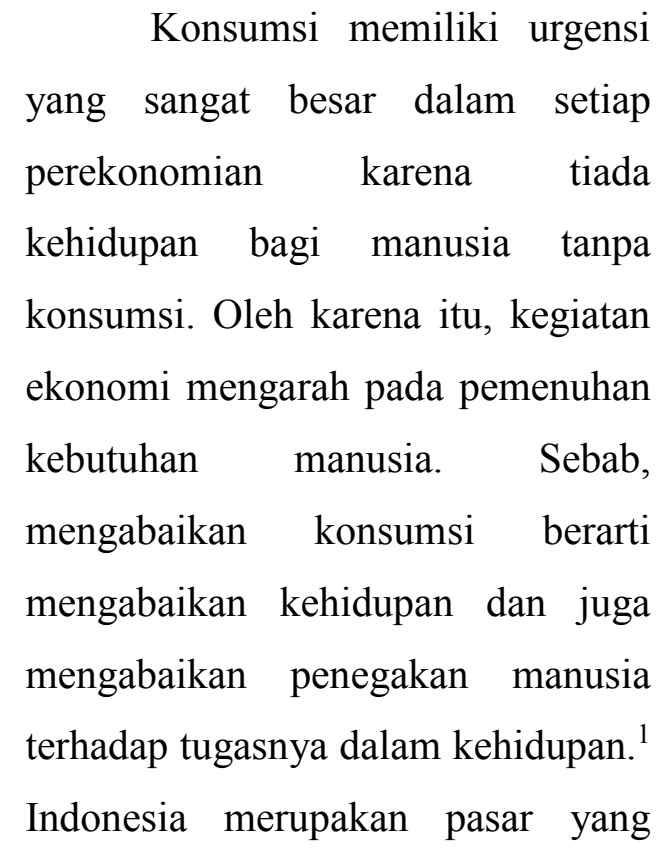

* Mahasiswa Magister Fakultas Hukum Universitas Padjadjaran

** Dosen Fakultas Hukum Universitas Padjadjaran

1 Jaribah bin Ahmad Al-Haritsi. (2006). Fikih Ekonomi Umar bin Al-Khatab. Khalifah. Jakarta. h.135 besar bagi pemasaran produk-produk halal. Melihat dari mayoritas penduduk Indonesia yang beragama muslim kehadiran produk dan pangan halal sudah menjadi suatu hal yang penting diatur dalam suatu perundang-undangan. Rekam jejak peraturan mengenai produk halal di mulai sejak maraknya kasus lemak babi di Indonesia. Sebagai tanggapan dari permasalahan perlindungan konsumen muslim dari maraknya pangan haram yang beredar dalam masyarakat MUI sebagai lembaga yang bertanggung jawab terhadap persoalan umat membentuk suatu lembaga yang menjamin kehalalan suatu produk. Pada tanggal 6 Januari 
1989 dibentuklah Lembaga Pengkajian Pangan, Obat-obatan dan Kosmetika MUI (LPPOM-MUI). Departemen Kesehatan pada saat itu juga merasa bertanggung jawab, maka melalui BPOM dilaksanakan pengurusan label halal di BPOM.

Akibat dualisme sistem hukum dalam mendapatkan fatwa halal dan label halal dilakukanlah penyederhanaan. Pada tanggal 21 Juni 1996 Departemen Agama, MUI dan Departemen Kesehatan bekerja sama kemudian menyatakan pengurusan sertifikat halal dilakukan oleh MUI melalui badan LPPOM MUI berdasarkan audit dari gabungan ketiga badan tersebut. Pengurusan label halal ini masijh bersifat sukarela jadi banyak produk halal yang tidak memberkan label halal pada prduknya. Hingga pada akhirnya pada tahun 2014 DPR RI mengesahkan UU No. 33 Tahun 2014 tentang Jaminan Produk Halal.

\section{Dalam Pasal 4 UUJPH} mewajibkan semua pelaku usaha yang ada di Indonesia termasuk produk yang beredar masuk dan diperdagangkan di wilayah Indonesia wajib sertifikasi halal. Menurut Undang-Undang Ini produk halal adalah produk yang dinyatakan halal oleh syariat Islam sedangkan Jaminan Produk Halal adalah kepastian hukum terhadap kehalalan suatu produk yang dinyatakan dengan sertifikat.

Tahun 2017 menjadi tahun yang penting dalam kelembagaan jaminan halal. Lembaga baru yang menggantikan posisi LPPOM MUI sebagai penjamin produk halal sudah dibentuk. Badan Penyelenggara Jaminan Produk Halal (BPJPH) didirikan berdasarkan amanat dari Pasal 5 UUJPH. Setelah dibentuknya BPJPH masih terlihat masalah yang banyak dihadapi dari pembentukannya, hingga saat ini MUI masih menjalankan kewenangan sesuai dengan pasal 59 dan 60 UUJPH hingga BPJPH berfungsi dengan baik. Ini berarti MUI sampai saat ini masih mengeluarkan label halal untuk pangan yang berada di Indonesia. BPJPH terkendala oleh pembahasan Peraturan Pemerintah (PP) terkait pelaksanaan Jaminan Produk Halal sedangkan pemerintah menargetkan tanggal 17 Oktober 2019 semua 
produk yang beredar di Indonesia harus bersertifikat halal. ${ }^{2}$

Perkembangan zaman akibat globalisasi telah merubah bentuk dari perlindungan konsumen baik secara umum atau pun secara khusus menyangkut pangan halal yang di konsumsi oleh konsumen muslim. Globalisasi itu diantaranya adalah globalisasi produk yang tidak hanya dibuat oleh satu negara, globalisasi finansial menyangkut peredaran uang yang tidak mengenal batas negara, globalisasi perdagangan yang menjadikan dunia sebagai pasar dalam perdagangan, serta globalisasi dalam hal teknologi yang mengarah pada moderenisasi mekanisme pembuatan produk. $^{3}$

Gaya hidup halal belakangan ini memang tengah melanda dunia. Perusahaan beskala global saat ini tengah menerapkan sistem halal seperti Japan Airlaines yang menyajikan panganan halal dalam cemilan pesawatnya. Di Jepang pernah diadakan Japan Halal Expo yang ramai kunjungan tiap tahun.

${ }^{2}$ ttps://khazanah.republika.co.id/berita/duniaislam/islam-nusantara/ppqvyk320/bpjph-semuaproduk-per-17-oktober-wajib-bersertifikat-halal diakses 5 Mei 2019

3 Sudjana dan Elisatris Gultom,( 2016). Rahasia Dagang dalam Perspektif Perlindungan Konsumen. Keni Media, Bandung.. h.5
Pameran ini berpengaruh pada 350 restoran yang ada di Jepang dengan menyajikan pangan halal sebagai menunya. ${ }^{4}$ Di mana letak indonesia sebagai negara yang penduduknya mayoritas muslim dalam menyediakan pangan halal. Indonesia menempati urutan kesepuluh dari negara pelaksana ekonomi islam itu.

Banyaknya produk yang dijual online belum sepenuhnya menjamin kehalalan suatu produk. Minimnya pelaku usaha yang tidak mencantumkan label halal dalam produknya terutama pada penjualan secara online perlu bahas secara mendalam dalam makalah ini. Melihat dari pentingnya perlindungan konsumen dalam transaksi elektronik karena banyak hak-hak konsumen yang terabaikan dalam transaksi ini dibandingkan hak konsumen pada pembelian secara langsung. Tidak diragukan lagi bahwa transaksi perdagangan secara elektronik memungkinkan pelaku usaha menjual barang (atau jasa) tanpa terlebih dahulu memperlihatkan kondisi fisik barang yang dijual kepada konsumen.

4 Asrorun Ni'am Sholeh, "Halal Jadi Tren Global" dalam GATRA Edisi 29 Juli 2015, h. 3435. 
Keadaan itu memberi keselamatan yang luas kepada pelaku usaha untuk menjual barang dan jasa yang kualitasnya tidak sesuai dengan apa yang sudah dijanjikan. Bahkan, konsumen sangat mungkin tidak mengetahui kredibilitas pelaku usaha yang menjual barang atau jasa tersebut. Oleh karena itu, cukup besar proporsi pelaku usaha untuk melakukan tindakan curang dalam aktivitas transaksi secara elektronik. ${ }^{5}$ Adalah penting untuk dicatat bahwa Pasal 17 ayat (1) UUPK juga melarang pelaku usaha membuat iklan yang mengelabui konsumen. Bahkan, ketentuan ini menegaskan bahwa pelaku usaha tidak boleh mencantumkan kualitas dan kuantitas barang, bahan, kegunaan, maupun harga barang ataupun jasa yang sifatnya mengelabui konsumen.

Ketimpangan antara undangundang dengan prakteknya di lapangan, membuat artikel ini mengangkat identifikasi masalahnya yaitu bagaimana jaminan perlindungan hukum terhadap penjualan produk tidak berlabel halal yang dijual secara online serta kendala apa saja yang harus

5 Sjahputra, I. (2010). Perlindungan Konsumen Dalam Transaksi Elektronik. Alumni, Bandung. h.160 diantisipasi oleh UU JPH guna melindungi konsumen muslim untuk mendapatkan produk halal dalam transaksi elektronik. Penelitian ini menggunakan metode penelitian yang melakukan kegiatan kajian literatur yakni dengan menggunakan buku sebagai bahan yang dipakai untuk menghimpun data-data atau sumber-sumber yang berhubungan dengan topik yang diangkat dalam penelitian. Penelitian ini juga mencari referensi melalui teori yang relevan dengan kasus dan permasalahan yang diteliti.

\section{B. PEMBAHASAN}

\section{Perlindungan Konsumen Terhadap Produk Halal Dalam Transaksi Elektronik.}

Konsumen dari $E$ Commerce dapat dibagi menjadi konsumen pembeli dari produk yang dijual secara online dan konsumen dari segi sistem informasi dan teknologi. Konsumen dari segi sistem informasi dan teknologi mencakup penjual dan pembeli yang disebut pengguna internet. Pengguna internet juga disebut konsumen termasuk di dalamnya penjual dan pembeli bagian dari penyelengara dari e-commerce. Pihak developer 
atau provider merupakan pihak yang menjadi produsen atau pelaku usaha dari e-commerce. Setidaknya terdapat tanggung jawab dari pengembang dan atau penyelengara sistem elektronik sebatas sistem yang telah ada dapat diyakini berjalan sebagaimana mestinya, risiko harus dapat dialihkan secara adil kepada para penggunanya. Dalam pembahasan ini konsumen yang akan dibahas dari segi konsumen yang membeli produk secara online dan melakukan transaksi secara online karena konsumen yang seperti ini dianggap lebih penting dalam mendapat perlindungan. ${ }^{6}$ Konsep $e$ commerce yang ada di Indonesia pelaku usaha yang menjual dagangannya di toko online sebagai patner dari e-commerce tersebut. Sedangkan pembeli dalam makalah ini adalah pembeli dari e-commerce merupakan konsumen akhir dari suatu produk bukan pembeli yang akan dijual kembali.

\section{Undang-Undang}

Perlindungan Konsumen yang digunakan sejak tahun 1999 belum sepenuhnya melindungi konsumen terutama konsumen e-commerce

${ }^{6}$ Adrian Sutedi. (2008). Tanggung jawab produk dalam hukum perlindungan konsumen. Ghalia Indonesia. Bogor h.7 karena hak-hak konsumen dari $e$ commerce belum sepenuhnya diatur dalam UUPK. Guna melihat hak apasaja hak apa saja yang tidak dilindungi dari e-commerce kita harus menanalisis ciri dari $e$ commerce yang menyebabkan hak konsumen terlanggar. Ciri tersebut adalah; 1) tidak bertemunya penjual dengan pembeli dan pembeli dari transaksi e-commerce. 2) media yang digunakan berbentuk semu atau maya tidak dapat dilihat dan dirasakan karena menggunakan internet sebagai media, 3) penjualan produk terkadang melewati batas yurisdiksi suatu negara sehingga tidak ada jaminan halal terhadap suatu produk, 4) terhadap produk yang melewati yurisdiksi penyelesaian sengketa menjadi hambatan negara mana yang berhak menyelesaikan sengketa konsumen.

Jika dikaitkan dengan UUPK dalam transaksi e-commerce hak-hak konsumen yang terlanggar adalah;

a) Hak atas keamanan dan ke selamatan dalam mengkonsumsi barang dan atau jasa. Ini berkaitan keamanan dalam pembayaran dan konsumen dalam mendapatkan barang. 
b) Hak atas informasi yang benar, jelas dan jujur mengenai kondisi suatu barang termasuk dalamnya pencantuman label halal, komposisi suatu barang.

c) Hak untuk di dengar pendapat dan keluhan atas suatu barang dan jasa yang digunakan

d) Hak mendapatkan advoksi, perlindungan dan upaya penyelesaian sengketa perlindungan konsumen secara patut. (dalam hal produsen di luar negeri yang berbeda yurisdiksinya. Dimana dalam penjelasan pasal 1 ayat 3 pelaku usaha adalah perusahaan korporasi BUMN importir pedagang distributor dan lainlain yang berkedudukan di wilayah hukum Indonesia.

e) Kerahasiaan data konsumen juga tidak tertuang dalam UUPK.

Dapat dikatakan hak-hak konsumen yang diakui secara universal tidak diterapkan dengan penuh dalam pemenuhan hak-hak konsumen pada transaksi elektronik. ${ }^{7}$ Ketidakberdayaan konsumen dalam

7 Barkatullah, A. H. (2007). Urgensi Perlindungan Hak-hak Konsumen Dalam Transaksi Di E-Commerce. Jurnal Inovasi dan Kewirausahaan, 14(2). menghadapi pelaku usaha ini jelas sangat merugikan kepentingan masyarakat. Pada umumnya pelaku usaha berlindung dibalik standard contract atau kontrak baku yang telah ditandatangani oleh kedua belah pihak (antara pelaku usaha dan konsumen). ${ }^{8}$

Tanpa perlindungan dan kepastian hukum bagi konsumen, maka Indonesia hanya akan menjadi ajang dumping barang dan jasa yang tidak bermutu dan tidak mementingkan masyarakat muslim dalam mendapatkan produk halal yang berasal dari luar negeri, yang lebih menghawatirkan, kesejahteraan rakyat yang dicita-citakan pun jadi lebih sulit diwujudkan. ${ }^{9}$ Dalam kasus-kasus pelanggaran hak konsumen, diperlukan kehati-hatian dalam menganalisis siapa yang harus bertanggung jawab dan seberapa jauh tanggung jawab dapat di bebankan kepada pihak-pihak terkait. $^{10}$ Diperlukan pendalaman siapa yang bertanggung jawab terhadap pelanggaran terhadap konsumen apakah produsen sebagai

8 Gunawan Widjaja dan Ahmad Yani. (2001). Hukum Tentang Perlindungan Konsumen. Gramedia Pustaka Utama. Jakarta. h. 1.

${ }^{9}$ Sudaryatmo, Op.Cit. h. 84

10 Sidarta. (2000). Hukum Perlindungan Konsumen. Grasido. Jakarta. h.59 
orang yang memproduksi atau toko online sebagai pihak yang mendistribusikan produk dan menyalurkan produk.

Kehatian-hatian konsumen menjadi penting dalam perlindungan konsumen melihat posisi tawar dari konsumen yang lemah konsumen harus bersikap waspada dan hati-hati dalam pembelian suatu produk (let the buyer beware). ${ }^{11}$ Kebanyakan dalam e-commerce konsumen tidak mendapat informasi yang yang memadai mengenai barang dan jasa yang akan di konsumsinya selain itu pelaku usaha juga tidak terbuka dalam menyampaikan informasi mengenai produk yang ditawarkan. Undang-undang perlindungan konsumen menganut pembuktian tebalik sehingga konsumen yang menuntut harus dapat membuktikan gugatannya.

Ada beberapa hal yang perlu diperhatikan guna terciptanya perlindungan terhadap konsumen terhadap barang-barang non halal yang beredar di Indonesia

11 Hutabarat, S. A. (2018). AsPek Perlindungan Hukum Terhadap Konsumen Dalam E-Commerce Di Internet Menurut Uu Nomor 8 Tahun 1999 Tentang Perlindungan Konsumen. Majalah Ilmiah INTI (Informasi dan Teknologi Ilmiah), 13(2), 120-124. a. Dari sisi produsen/pelaku usaha

1) Pelaku usaha diwajibkan mencantumkan identitas yang lengkap mengenai kedudukan pelaku usaha dan kontak yang bisa dihubungi untuk menanyakan produk dalam website.

2) Adanya lembaga yang menjamin keabsahaan toko online. Termasuk dalam menjamin kehalalan suatu produk.

b. Dari sisi konsumen

1) Konsumen dari toko online harus mendapatkan informasi yang benar dan mencari tahu kualitas produk dan kehalalan produk di samping keunggulan produk. Pelaku usaha di indonesia dalam mendeskripsikan suatu produk sangat minim informasi yang hanya menyebutkan harga dan penjelasan yang sedikit.

2) Informasi produk harus menggunakan bahasa yang dimengerti oleh konsumen sehingga tidak menimbulkan penafsiran lain dari informasi tersebut. 
3) Memberikan jaminan bahwa produk yang ditawarkan aman atau nyaman untuk di konsumsi dan dipergunakan.

4) Menjamin produk sesuai dengan apa yang dipromosikan.

Harmonisasi antar Undang-Undang Perlindungan Konsumen, Undang-Undang Jaminan Produk Halal dan UndangUndang Informasi Transaksi Elektronik dinilai penting ini terkait dengan banyaknya produk yang tidak berlabel halal yang dijual dalam $e$ commerce. $^{12}$ Jaminan produk halal yang akan diterapkan oleh BPJPH pada Oktober 2019 mendorong semua produk yang beredar di Indonesia harus berlabel halal termasuk produk-produk yang dijual secara online. Kebanyakan produk yang di produksi oleh UMKM yang berada di daerah yang tidak terjangkau oleh keberadaan BPJPH atau pun LPPOM-MUI menjadi masalah karena produknya bisa dijual secara e-commerce tanpa mencantumkan label halal. Jika ditemukan dalam produk tersebut

12 Suparto, S., Djanurdi, D., Yuanitasari, D., \& Suwandono, A. (2016). Harmonisasi Dan Sinkronisasi Pengaturan Kelembagaan Sertifikasi Halal Terkait Perlindungan Konsumen Muslim Indonesia. Mimbar Hukum-Fakultas Hukum Universitas Gadjah Mada, 28(3), 427-438. yang mengandung dari bahan-bahan yang unsur haram maka pertanggungjawabanya bukan hanya kepada produsen tetapi juga pelaku usaha e-commerce bertanggung jawab terhadap produk yang di iklankan dan di distribusikanya.

\section{Kendala yang Harus Diantisipasi dalam Pelaksanaan UUJPH Terhadap Penjualan Produk Secara Online.}

Perkembangan teknologi sekarang ini dengan adanya industri 4.0 banyak bahan-bahan haram tersebut yang dimanfaatkan sebagai bahan baku, bahan tambahan dan bahan penolong pada pengolahan produk. Disamping itu produk olahan menjadi diragukan kehalalanya (syubhat) karena prosesnya tidak sesuai dengan syariat islam. Misalnya dalam pemotongan hewan yang menggunakan mesin yang tidak menggunakan syariat Islam sehingga tidak jelas status kehalalannya.

Undang-Undang Jaminan Produk Halal merupakan payung hukum dalam memberikan perlindungan konsumen khusus konsumen muslim. Dengan adanya 
UU JPH mengharuskan semua produsen untuk menghasilkan produk yang halal. Ini tergambar dalam pasal 4 UU JPH. Sebelum UUJPH di sahkan, sertifikat halal bukan merupakan suatu keharusan. Sertifikat halal merupakan sesuatu hal yang bersifat sukarela bagi produsen yang membutuhkan label halal dari produknya dengan mempertimbangkan manfaat yang didapat dari pelabelan tersebut. Manfaat lain dari adanya label tersebut adalah pertanggungjawaban produsen kepada konsumen muslim mengingat masalah halal merupakan bagian dari prinsip hidup muslim, meningkatkan kepercayaan dan kepuasan konsumen, meningkatkan citra dan daya saing perusahaan, sebagai alat pemasaran dan untuk memperluas area jaringan pemasaran serta memberi keuntungan pada produsen dengan meningkatkan daya saing dan omzet produksi dan penjualan.

\section{Menjadi kewenangan} LPPOM MUI yang selama ini dalam pengurusan sertifikasi halal tersebut sebelum keluarnya UUJPH, LPPOM MUI mengenakan biaya untuk proses pengujian dan sertifikasi karena lembaga ini dibentuk secara swadaya yang independen dan membutuhkan dana sebagai penggerak operasionalnya. Sudah sewajarnya LPPOM MUI mengenakan biaya kepada pengusaha yang akan memberikan label halal pada produknya.

$$
\text { Kedudukan }
$$

UUJPH menjadi penting sejak disahkan pada tahun 2014 silam karena; 1) UU ini memberi kepastian dalam mengatur mengenai produk halal yang selama ini belum memberikan kepastian hukum, 2) Adanya kepastian hukum badan/institusi yang akan mengurus jaminan produk halal dan melibatkan negara dalam pengurusannya. 3) Meningkatnya produk di pasar domestik akibat perkembangan teknologi dan mengakibatkan sulit di kontrol keberadaanya. 4) Produk halal Indonesia belum memiliki standar resmi dan tanda halal resmi yang ditetapkan oleh pemerintah layaknya Malaysia. 5) Sistem informasi produk halal belum sesuai dengan tingkat pengetahuan dan kebutuhan masyarakat tentang produk halal.

Setelah dibentuknya BPJPH masih terlihat masalah yang banyak dihadapi dari pembentukannya, hingga saat ini 
LPPOM-MUI masih menjalankan kewenangan sesuai dengan pasal 59 dan 60 UUJPH hingga BPJPH berfungsi dengan baik. Ini berarti MUI sampai saat ini masih mengeluarkan label halal untuk pangan yang berada di Indonesia. BPJPH terkendala oleh pembahasan Peraturan Pemerintah (PP) terkait pelaksanaan Jaminan Produk Halal sedangkan pemerintah menargetkan tanggal 17 Oktober 2019 semua produk yang beredar di Indonesia harus bersertifikat halal.

Sertifikat Halal yang telah ditetapkan oleh LPPOM MUI sebelum UU No. 33 Tahun 2014 berlaku dinyatakan tetap berlaku sampai jangka waktu Sertifikat Halal tersebut berakhir. Sebelum BPJPH dibentuk, pengajuan permohonan atau perpanjangan Sertifikat Halal dilakukan sesuai dengan tata cara memperoleh Sertifikat Halal yang berlaku sebelum UU No. 33 Tahun 2014 diundangkan. MUI tetap menjalankan tugasnya di bidang Sertifikasi Halal sampai dengan BPJPH dibentuk dan LPH yang sudah ada sebelum UU No. 33 Tahun 2014 berlaku diakui sebagai LPH dan wajib menyesuaikan paling lama 2 (dua) tahun terhitung sejak BPJPH dibentuk, demikian pula dengan Auditor halal dan Penyelia Halal.

Ada beberapa isu yang menerpa LPPOM MUI sebagai lembaga yang mengeluarkan sertifikat halal diantaranya, ${ }^{13}$ Pertama dari sisi kelembagaannya LPPOM MUI dituding sebagai lembaga yang memonopoli dalam pemberian sertifikat halal. Pernyataan itu memang ada benarnya tetapi pada kenyataan pemberian sertifikat halal bukan merupakan keharusan dan sifatnya sukarela. LPPOM MUI juga terdapat di 33 Provinsi yang setiap daerah memiliki otoritas sendiri yang tidak tergantung pada LPPOM pusat. Kedua, standarisasi dalam penetapan sertifikat halal tidak ada rincian mengenai bahan yang boleh dan bahan yang tidak boleh dalam penggunaan terhadap produk. Standar dari sistem manajemen penerbitan juga tidak ada. Tetapi dalam Agama Islam telah memberikan keterangan dengan jelas mengenai halal dan haram suatu bahan makanan yang tidak perlu diperdebatkan lagi. Ketiadaan standar bagi lembaga sertifikasi halal

13 Sayekti, N. W. (2014). Jaminan Produk Halal dalam Perspektif Kelembagaan. Jurnal Ekonomi dan Kebijakan Publik, 5(2), 193-209. 
seringkali menyulitkan dalam menetapkan apakah suatu lembaga sertifikasi halal dari luar negeri sertifikatnya bisa diakui atau tidak. Ketiga, mengingat persaingan global banyak lembaga-lembaga sertifikat halal yang berada di luar negeri yang sering dikelola swasta terutama oleh negara yang penduduknya minoritas muslim. Dengan menjadikan pengelolaan sertifikasi halal oleh swasta lebih memberikan persaingan guna meningkatkan kualitas dari lembaga pemeriksa halal.

Perpindahan pengurusan serifikasi halal dari LPPOM MUI kepada BPJPH telah melalui proses yang matang dengan mempertimbangkan keunggulan dan kelemahan masing-masing lembaga. LPPOM MUI sebagai lembaga yang telah lama di bentuk memiliki beberapa keunggulan yaitu; ${ }^{14}$

a) Dari segi inftrastruktur dan sistem yang sudah berpengalaman dalam menerbitkan sertifikasi halal. Bahkan sekarang LPPOM MUI telah menggunakan kemajuan teknologi dalam pengajuan sertifikatsi halal. Pengajuan

\footnotetext{
${ }^{14}$ Ibid.
}

sertifikasi halal dapat dilakukan secara online sehingga dapat menjangkau UMKM di daerah.

b) LPPOM MUI merupakan bagian dari MUI yang merupakan organisasi keagamaan yang sudah diakui di Indonesia sehingga penetapan halal atau tidaknya suatu produk melalui musyawarah para ulama yang sudah berkompeten.

c) Alur pendaftaran hingga diterbitkan sertifikasi halalnya tergolong singkat, sederhana dan pendek.

d) Dari segi historis LPPOM MUI sudah berpengalaman dalam memeriksa kehalalan suatu produk, bahkan lembaga ini sudah melakukan kerjasama dengan luar negeri guna meningkatkan kemampuan dan sumber daya.

e) Penggunaan subsidi silang dalam membiayai penerbitan sertifikasi halal di anggap tidak akan mengurangi APBN dan APBD.

Dari keunggulan diatas ada beberapa hal yang menjadi pertimbangan pemerintah sehingga menyebabkan pemerintah harus 
membuat UUJPH, diantara kekurangan itu adalah; ${ }^{15}$

a) Landasan hukum pembentukan LPPOM MUI kurang kokoh sehingga menyebabkan tidak adanya peraturan yang menjadi payung hukum dari pelaksanaan LPPOM MUI.

b) Pengurusan sertifikat halal bukan merupakan suatu keharusan yang menyebabkan banyak pelaku usaha enggan menjamin produknya dengan label halal.

c) Terbatasnya sumber daya manusia yang menjadi auditor di LPPOM MUI

d) Akibat bukan suatu lembaga pemerintah menyebabkan dukungan $\mathrm{APBN}$ dan dana dari pemerintah masih sedikit dan cendrung menggunakan swadaya yang bersifat mandiri.

e) Lembaga yang bersifat mandiri ini menyebabkan tidak adanya pendapatan yang masuk ke kas negara.

Pertimbangan-

pertimbangan di atas menjadikan pemerintah harus membentuk suatu undang-undang yang menjamin produk halal dan menjadi tanggung jawab negara dalam melindungi konsumen muslim. Di dunia ada dua kelompok negara yang mengatur tentang kelembagaan jaminan produk halal. Kelompok negara yang pertama negara yang minoritas penduduk muslimnya, setiap lembaga LPH merupakan suatu organisasi yang berdiri sendiri dan tidak ada kaitan dengan negara atau dengan kata lain berbadan hukum swasta. Kelompok negara kedua adalah LPH merupakan buatan dari pemerintah dan merupakan bagian dari pemerintah yang mengikuti aturan dari pemerintah. Indonesia dengan adanya UUJPH pemerintah memegang penuh jaminan jaminan produk halal. Ada beberapa hal yang menjadi kelebihan dari negara sebagai pemegang jaminan produk halal;

a) Penyelenggaraan jaminan halal menjadi terorganisir dan keberadaan LPH dapat di kontrol oleh pemerintah

b) Mempunyai kekuatan hukum karena diatur dalam undangundang 
c) Kewajiban untuk mempunyai sertifikat halal diwajibkan kepada semua pelaku usaha

d) Adanya dukungan dari APBN dan APBD karena merupakan lembaga yang didirikan oleh pemerintah

e) Dengan menjadi satu bagian dari pemerintah, maka ada pemasukan di luar pajak

f) Masa berlaku sertifikat relatif panjang yaitu selama 4 (empat) tahun.

Dalam pelaksanaannya UUJPH mengalami kendala-kendala yang perlu di perhatikan seperti ;

a) Memerlukan waktu untuk tansisi dari LPPOM MUI ke JPH dan juga meningkatnya beban APBN dan APBD akibat pembentukan $\mathrm{BPJPH}$

b) Alur dan proses menjadi panjang dan melibatkan lembagalembaga terkait,

c) Rawan konflik kepentingan antara LPH pemerintah dan LPH swasta LPPOM MUI akan kemudian menjadi salah satu bagian $\quad$ LPH. MUI berkemungkinan mendominasi

LPH,

d) Pelaku usaha tetap dikenakan biaya walaupun menjadi kewajiban pemerintah untuk memberikan jaminan produk serta

e) Membutuhkan pengaturan yang lebih dalam PP dan peraturan pelaksana lain guna meningkatkan akuntabilitas dan trasparasi.

f) Kontradiksi antar peraturan, pembuatan peraturan pelaksana dari UUJPH berkemungkinan berbenturan dengan peraturan lainnya.

Guna menghadapi kendala dalam pelaksanaan UUJPH ada catatan penting yang perlu dibenahi Pertama, Diperlukan peraturan yang lebih tegas. Banyak produk yang tidak mencantumkan label halal tetapi produk yang dihasilkan daru bahan baku yang halal. Produkproduk yang seperti ini terkendala oleh biaya dan proses yang panjang. Penghalalan semua produk yang akan dikonsumsi oleh muslim sesuai pasal 4 UUJPH mengalami kendala sulit diterapkan karena ada produk 
daging segar, produk dari produsen kecil dan jajanan.

Kedua, Produsen yang memiliki sistem jaminan halal harus berhati-hati dalam memilih bahan apa saja yang haram dan halal. Perlu diterapkan Halal Analysis Critical Control Point yang memeriksa pada titik-titik tertentu dalam proses produksi yang kemungkinan masuknya bahan haram. Dengan adanya sistem ini masuknya bahan haram ke suatu produk dapat dicegah sejak awal.

Ketiga, dari konsumenya harus lebih kristis lebih peduli terhadap makanan dan minuman yang dikonsumsinya karena ternyata masih banyak makan yang syubhat. Setiap muslim harus belajar dan mendalami lagi hukum-hukum islam. Diperlukan kerja keras ulama dalam menemukan bahan yang masih belum jelas kehalalannya dengan berkerjasama dengan ilmuan.

\section{KESIMPULAN}

Tidak seimbangnya posisi tawar konsumen dalam transaksi elektronik menyebabkan perlunya pengaturan mengenai perlindungan konsumen dalam transaksi elektronik. Mengingat hak-hak konsumen dalam UU Perlindungan Konsumen banyak yang tidak diterapkan dalam transaksi elektronik. Salah satu hak konsumen yang dilanggar adalah konsumen berhak mendapatkan informasi mengenai suatu produk. Umat muslim yang diharuskan dalam agama mengkonsumsi produk yang berbahan halal menjadi penting dalam perlindungan konsumen. Dalam pembelian secara elektronik pembelian produk yang minim informasi dan tidak bertemunya penjual dan pembeli menjadi penyebab banyaknya produk tidak halal yang beredar di E-Coommerce. Pemerintah Indonesia telah menerbitkan UU No. 33 Tahun 2014 Tentang Jaminan Produk Halal, dalam Pasal 4 UUJPH tersebut mengharuskan semua pelaku usaha mencantumkan label halal dalam produknya yang beredar di Indonesia. Harmonisasi antar Undang-Undang Perlindungan Konsumen, Undang-Undang Jaminan Produk Halal dan UndangUndang Informasi Transaksi Elektronik dinilai penting ini terkait dengan banyaknya produk yang tidak berlabel halal yang dijual dalam e-commerce. 
Beralihnya lembaga yang berwenang dalam hal penjaminan produk halal dari LPPOM MUI kepada BPJPH yang sebagai mana diatur dalam UUJPH guna melibatkan negara terhadap perlindungan konsumen di Indonesia. Dalam pelaksanaanya Badan Penyelenggara Jaminan Produk Halal (BPJPH) didirikan berdasarkan amanat dari Pasal 5 UUJPH belum berjalan sebgaimana mestinya, hingga saat ini MUI masih menjalankan kewenangan sesuai dengan pasal 59 dan 60 UUJPH hingga $\mathrm{BPJPH}$ berfungsi dengan baik. Ini berarti MUI sampai saat ini masih mengeluarkan label halal untuk pangan yang berada di Indonesia. BPJPH terkendala oleh pembahasan Peraturan Pemerintah (PP) terkait pelaksanaan Jaminan Produk Halal dilain pihak pemrintah didesak oleh kebijakan bahwa tertanggal 17 Oktober 2019 semua produk yang beredar di Indonesia harus bersertifikat halal.

\section{DAFTAR PUSTAKA}

\section{Buku}

Adrian Sutedi. (2008). Tanggung jawab produk dalam hukum perlindungan konsumen. Ghalia Indonesia.

Bogor.

Al-Faizin., \& Akbar, N. (2010). Tafsir Ekonomi Kontemporer. Madani Publishing House. Jakarta.

Asrorun Ni'am Sholeh, "Halal Jadi Tren Global” dalam GATRA Edisi 29 Juli 2015.

Gunawan Widjaja dan Ahmad Yani. (2001). Hukum Tentang Perlindungan Konsumen. Gramedia Pustaka Utama. Jakarta.

Husni Syawali dan Neni Sri Imaniyati. (2008). Hukum Perlindungan Konsumen. Mandar Maju. Bandung.

Jaribah bin Ahmad Al-Haritsi. (2006). Fikih Ekonomi Umar bin AlKhatab. Khalifah. Jakarta.

Maskun dan Wiwik Meilarati Saloko. (2017). Aspek Hukum Penipuan Berbasis Internet, Keni Media, Bandung.

Sidarta. (2000). Hukum Perlindungan Konsumen. Grasido. Jakarta.

Sjahputra, I. (2010). Perlindungan Konsumen Dalam Transaksi Elektronik. Alumni, Bandung. 
Sudaryatmo. (1999). Hukum dan Advokasi Konsumen. PT. Citra Aditya Bakti, Bandung.

Sudjana dan Elisatris Gultom, (2016). Rahasia Dagang dalam Perspektif Perlindungan Konsumen. Keni Media, Bandung.

\section{Jurnal}

Suparto, S., Djanurdi, D., Yuanitasari, D., \& Suwandono, A. (2016). Harmonisasi Dan Sinkronisasi Pengaturan Kelembagaan Sertifikasi Halal Terkait Perlindungan Konsumen Muslim Indonesia. Mimbar HukumFakultas Hukum Universitas Gadjah Mada, 28(3).

Barkatullah, A. H. (2007). Urgensi Perlindungan Hak-hak Konsumen Dalam Transaksi Di E-Commerce. Jurnal Inovasi dan Kewirausahaan, 14(2).

Hutabarat, S. A. (2018). Aspek Perlindungan Hukum Terhadap Konsumen Dalam E-Commerce Di Internet Menurut Uu Nomor 8 Tahun 1999 Tentang Perlindungan Konsumen. Majalah Ilmiah INTI (Informasi dan Teknologi Ilmiah), 13(2).
Sayekti, N. W. (2014). Jaminan Produk Halal dalam Perspektif Kelembagaan. Jurnal Ekonomi dan Kebijakan Publik, 5(2).

Agus, P. A. (2017). Kedudukan sertifikasi halal dalam sistem hukum nasional sebagai upaya perlindungan konsumen dalam hukum Islam. AMWALUNA: Jurnal Ekonomi dan Keuangan Syariah, 1(1).

\section{Website}

https://khazanah.republika.co.id/berita/du nia-islam/islamnusantara/ppqvyk320/bpjphsemua-produk-per-17-oktoberwajib-bersertifikat-halal diakses 5 Mei 2019 